\title{
The Effects of User Comments on e-Trust: An Application on Consumer Electronics
}

\author{
Emre Yıldırım, Member, IACSIT
}

\begin{abstract}
In this study it's aimed to determine the effects of user comments to build trust in virtual environments. 350 people existing of students and employees were selected from Sakarya University. The data gained from the sample size, analyzed with factor analysis, t-test and analysis of variance (anova). When the results obtained from analysis evaluated, the conclusion that user comments decrease the uncertainty and affect trust perception has been reached.
\end{abstract}

Index Terms-E-Commerce, user comments, consumer electronics, e-trust, e-security.

\section{INTRODUCTION}

In recent years, development of information technologies accelerated the transition from industrial society to information society. This development of information technologies has created a new economic system which is called electronic commerce (e-commerce). This new economic system has changed the nature of trade in the way of face to face. However, the digitization of transactions has created an uncertain environment. Because of the reasons such the parties don't recognize each other, the products can't be observed physically, the absence of mutual communication, the delivery and the payment don't take place at the same time and the theft of privacy information, trust becomes more important in e-commerce.

\section{TRUST AND COMPONENTS}

Definitions about trust in the literature as follows;

- Trust is defined as willingness to rely on the other partner of the relationship [1].

- Trust is the expectation of belief that any opportunistic behavior will appear by others [2].

- In the basis of trust there are concepts such truth, candour, sincerity and reality [3].

- Trust increases when expectations of the other party are consistently and reliably met,and decreases when the other party acts otherwise [4].

As a result, trust is the term that helps people to relate with others positively, results transactions correctly and removes the uncertainty.

With the help of these definitions we can explain the three components of trust like this [5];

1) Trust, reflects expectations about counterpart's anticipated action in good will.

Manuscript received January 18, 2013; revised April 24, 2013.

E. Y1ldirım is with the Business Administration of Sakarya University, Sakarya, Turkey (e-mail: emreyildirim@ @akarya.edu.tr).
2) Counterpart can't control this conviction. Put another way, there is a risk of expectations that being unfulfilled.

3) One's performance depends on the actions of the counterpart. In other words there is the principle of reciprocity.

Trust can be distinguished into personal and impersonal. Personal trust is subjective and is formed by an individual based on beliefs, observations, communication and past experiences [6]. In other words it is the trust choice of person by using past experiences as a reference. For example think about a man who shops from a website. Presume that by taking into account product features and benefits, he has selected the most appropriate one. After delivery, if the product which he wants to purchase is different, he won't tend to make shopping from that website.

However sometimes personal trust is impossible because of the situational constraints. At that time impersonal trust sets in. Impersonal trust arises when direct contact between partners is unavailable or faceless [7]. Put another way, impersonal trust appears when individual can't evaluate conditions directly. Word of mouth can be shown as an example of impersonal trust. Continuing with the previous example, he directs inexperienced friends to avoid shopping from that website by using the negative effect of word of mouth.

\section{TRUST IN E-COMMERCE}

The rapid growth of the e-commerce from the late 1990s makes trust more important in online transactions. Because, there is not a face to face relationship among parties and buyers can't purchase physically by touching and testing in online transactions [8]. Furthermore it's the other problem that the exchange of product and payment don't occur at the same time [9]. In other words, payment comes first.

The main reason of this uncertainty risk comes from information asymmetry in e-commerce. Information asymmetry is the situation in which one party has information that the other party does not have [10]. In other words, the reason of this information asymmetry is unobservability. Because of unobservability, goods and also services are perceived to be intangible in e-commerce. Because, consumers are not able to see, test, touch or smell the goods as tangible before they purchase [11].

When we compare e-commerce and offline shopping, privacy concern and information asymmetry become more important in e-commerce. Because in offline shopping consumers know the seller although they don't know anything about goods or services. In such a case, consumers impute seller's reputation to goods or services and then 
purchase confidently.

Because of the global nature of the internet as a virtual network, the trust concept has even greater importance than offline shopping. The reasons as follows [12];

- First, the other party that being dealt with may be unknown.

- Second, control deficiency of the transfer process of goods or services from seller to buyer.

- Third, different rules and procedures about the parties they locate.

It is obvious that e-commerce transactions are always uncertain. People complete the transactions only when they pass or at least equal the trust threshold. In a phrase, the person should trust firstly the transaction, parties and the all process. Thus, the transactions can be completed successfully.

To avoid from this uncertainty, there are some factors to build trust in e-commerce like below;

- E-commerce knowledge is the knowledge about product searching through an internet shopping mall, purchasing methods, payment processes, and individual information protection policies [13]. E-commerce knowledge evolves with the use and experience of the internet.

- Company's reputation is more important in online transactions. Because, consumers are faced with the possibility of exposure to fraud. For this reason companies use reputation systems in order to encourage trust [14].

- Perceived risk is the third factor to build trust in virtual environments. During the process of buying, the buyer's level of risk perception forms the basis of the trust concept. Risk perception also determines the level of trust. When the perception is high a strong effort and a long time are needed to build trust [15].

- Perceived ease of use is associated with website usability. Website usability can be defined as the ease of navigating the site or the realization of acquisitions [16]. This ease of use is especially more important in the first encounter in the process of searching for information [17].

- Security systems are also beneficial to build trust. Because, consumers feel in confidence with the help of these systems. Mostly used systems are SSL, SET, https, the sign of padlock near the address bar, etc.

- Contact information is seen as a sign of trust factor by consumers. Because of the absence of face to face communication, when consumers encounter a problem they want to contact with the company via telephone, e-mail, etc.

- User comments are the last factor to build trust and will be examined in the next chapter.

\section{USER COMMENTS}

User comments can be defined as the sharing of the positive or negative impressions that have gained about the product or service by individuals who have purchased from the internet. Thus, these impressions give instructions to other users and help what should do. The impressions of consumers' may be relevant to the product or service; furthermore brand, website, customer service and so on.

The two roles of the online user comments are providing information about goods and services as well as recommendation of them [18]. Online user comments are one of the most powerful channels to generate online word of mouth [19]. Because, they are a sign of shopping that being done and have impressions about the procedure.

The reasons that direct users to comment about the goods are described as follows [20];

- Alturism means writing online comments about products or services in order to help other online users. Alturism is important for customers to establish communication with each other.

- Social interaction desire is associated with social psychology. This theory assumes that people want to compensate their lives. For example when consumers purchase something, they tend to share positive or negative impressions about this product. Because, this social media with other users is a result of self-actualization needs.

- Product involvement based on the relationships between shopping and product. If the customer has a high praise about the product, he/she would be willing to write positive comments; if not will write negative ones.

- Help or revenge enterprise means that people have a motive help or blow enterprise to participate in word of mouth.

\section{APPLICATION}

Population of the research as of the 2011-2012 academic year consists of Sakarya University students and staff. During the process of the selection of the sample, students and staff were asked whether they bought any electronics before from the internet and have been added who bought at least once. Totally 640 surveys were sent to students and staff via e-mail. After an elimination, 350 (sufficient according to MacCallum [21] with an example of 5 or 10 multiple phrase) surveys has been shown to be suitable and included in the sample.

During the process of creating the scale, 25 phrases were developed. Two of them were selected from the study of Kim [22] and the others were developed with the help of an interview. Likert scale with 5 has been used in this study and performing a pilot study with 15 people a clearer understanding of some of the expressions for the re-arranged.

The result of reliability analysis of this study is 0,876 (> 0,70 ) which means the phrases are consistent with each other. In addition, the result of KMO analysis is 0,922 and Bartlett's Test is $0,000(<, 05)$ which means an adequate sample size.

Data generated in the scope of application, is shown at the Table I, II, III, IV and V. Table I is associated with sampling, the second one is related to status of trust, third is about hypothesis results, the fourth is opinions about user comments and the last one is associated with factors. 
TABLE I: SAMPLING DATA

\begin{tabular}{|c|c|c|}
\hline \multirow{2}{*}{$\begin{array}{c}\text { Internet Usage } \\
\text { Level }\end{array}$} & Beginner \& Moderate & 176 \\
\hline & Top & 174 \\
\hline \multirow{2}{*}{ Gender } & Male & 224 \\
\hline & Female & 126 \\
\hline \multirow{4}{*}{ Age } & $16-23$ & 115 \\
\hline & $24-31$ & 144 \\
\hline & $32-39$ & 61 \\
\hline & $40+$ & 30 \\
\hline \multirow{3}{*}{ Education } & High school & 125 \\
\hline & University & 52 \\
\hline & Master & 173 \\
\hline \multirow{2}{*}{ Occupation } & Staff & 212 \\
\hline & Student & 138 \\
\hline \multirow{4}{*}{$\begin{array}{l}\text { Monthly } \\
\text { Revenue }\end{array}$} & Less than $1500 \mathrm{TL}$ & 48 \\
\hline & $1501-2250 \mathrm{TL}$ & 153 \\
\hline & $2251-3000 \mathrm{TL}$ & 89 \\
\hline & $3001 \mathrm{TL}+$ & 58 \\
\hline
\end{tabular}

When we look at the Table I we can say the percentage of the internet usage level of the sample is almost equal. Furthermore users are considerably male with a $64 \%$ percent. In addition we can say users those who shop on the internet can be called as a young group with an integrated (16-31) $74 \%$ percentage. When we look into the education level, those who purchase from the internet are educated with a $49 \%$ percent. Participants are considerably staff. Last, the revenue is considerably between 1501-3000 TL with a percent of 70 .

TABLE II: STATUS OF TRUST RELATED TO USER COMMENTS

\section{Phrases}

\begin{tabular}{lc}
\hline I trust user comments. & 2,45 \\
\hline $\begin{array}{l}\text { User comments are effective to build trust through e-retail } \\
\text { website. }\end{array}$ & 2,23 \\
\hline $\begin{array}{l}\text { User comments are effective to build trust through } \\
\text { electronic product. }\end{array}$ & 2,25 \\
\hline $\begin{array}{l}\text { User comments are effective to build trust through the } \\
\text { brand. }\end{array}$ & 2,35 \\
\hline $\begin{array}{l}\text { User comments are effective to build trust through } \\
\text { e-shopping. }\end{array}$ & 2,35 \\
\hline
\end{tabular}

I believe that previous users wrote comments sincerely.

I don't believe in the existence of fake user comments which have been posted to trick consumers.

I believe that e-retail websites are impartial while publishing the user comments.

The number of user comments is important for me as the content to build trust.

Status of trust of the participants related to user comments is shown at the Table II. Likert measuring range is from 1 (strongly agree) to 5 (strongly disagree). Accordingly, participants denoted that they trust user comments. However, the level of participation is not very strong. The reasons for this firstly, participants are undecided about the comments written sincerely by other users. Secondly, we can see the fake user comments which have been posted to trick consumers.

When we consider the mean, user comments occur in a specific order. The order is from first one to the end like this; the website, the product, the brand and the e-shopping. It can be said that user comments are firstly used to generate attitudes towards e-retail website.

Hypothesis:

H1: The effect of user comments varies according to the level of internet usage.

$\mathrm{H} 2$ : The effect of user comments varies according to the gender.

H3: The effect of user comments varies according to the age group.

H4: The effect of user comments varies according to the level of education.

H5: The effect of user comments varies according to the occupation.

H6: The effect of user comments varies according to the monthly revenue.

\begin{tabular}{|c|c|c|c|c|}
\hline & $\begin{array}{r}\text { TABLE } \\
\text { T-test }\end{array}$ & $\begin{array}{r}\text { НYPOTH } \\
\text { Anova }\end{array}$ & TEST RE & \\
\hline & $\mathrm{p}$ & $\mathrm{p}$ & group & $\mathrm{p}$ \\
\hline H1 & ,813 & & & \\
\hline $\mathrm{H} 2$ & ,862 & & & \\
\hline $\mathrm{H} 3$ & &, $015 *$ & $32-39$ &, $027 *$ \\
\hline $\mathrm{H} 4$ & &, $010 *$ & Master &, $019 *$ \\
\hline $\mathrm{H} 5$ & ,000* & & & \\
\hline H6 & & ,903 & & \\
\hline
\end{tabular}

According to the Table III, H1, H2 and H6 were not found significant. In other words, the effect of the user comments is similar according to the level of internet usage, gender and monthly revenue. Because internet usage group consist mostly moderate users which is similar to the top. Likewise at the present time there are not big differences between male and female in terms of using the internet. When we analyze the others we can see the signification of H3, H4 and H5. According to $\mathrm{H} 3$, the participation level of the group 32-39 is lower than others. In other words, a certain level of participation decreases with increasing age up to the age. Because, life experience and education level increase with age. According to $\mathrm{H} 4$, the participation level of the master group is lower than others. So it can be said that education level and the trust effect of user comment is inversely proportional. Because, the consumers with more information about the system are more suspicious to shop from the internet. H5 means that the effect of user comments varies according to the occupation. The reason for this can be explained like that the staff is more trained and also have a higher education level than students.

As a result the effects of user comments to build trust are associated with e-commerce knowledge, perceived risk, perceived ease of use and security systems. E-commerce knowledge and perceived risk are related to lifetime experience which shows us with age group in H3. Because 
more experienced consumers surf the internet easily and know what to do during the e-shopping process and this decreases the perceived risk which creates uncertainty. Moreover, perceived ease of use and security systems can be associated with education level (H4). Because more educated consumers know the vulnerability in virtual environment and this makes them more controlled.

TABLE IV: OPINIONS RELATED TO USER COMMENTS

\begin{tabular}{llc}
\multicolumn{1}{c}{ Phrases } & \\
\hline $\begin{array}{l}\text { I read user comments before purchasing electronic } \\
\text { products. }\end{array}$ & 1,58 \\
\hline $\begin{array}{l}\text { User comments provide convenience to reach knowledge } \\
\text { of electronic products. }\end{array}$ & 1,87 \\
\hline $\begin{array}{l}\text { User comments provide convenience to compare } \\
\text { electronic products. }\end{array}$ & 1,91 \\
\hline I believe that user comments are beneficial. & & 1,86 \\
\hline $\begin{array}{l}\text { Positive user comments effect electronic product } \\
\text { purchasing decision. }\end{array}$ & 2,12
\end{tabular}

As seen at the Table IV, consumers indicate that they read user comments before the e-shopping. Because user comments provide knowledge about the website, product, company etc. with the help of word of mouth. The reason why previous users write comments is altruism. Furthermore, user comments make the e-shopping process easier and allow the users to compare product even websites. These increase the e-commerce knowledge and decrease the uncertainty. Participants are like-minded about the benefit of the user comments. Because user comments build trust through the e-retail websites in the virtual environment. Finally, it can be seen from the table, consumers are affected from the positive comments. This can be associated with product involvement and help or revenge enterprise. Because if the person has a positive impression, he/she affect following users' purchase decision. In the same way if not, he/she will also affect negatively.

While determining the factor loads initially, some of the 25 phrases have been removed due to low factor load and two factors obtained totally. The first of these factors is $34.664 \%$ of the total variance percent, and the latter $17.193 \%$ percent explains. In other words, approximately $52 \%$ of the total variance illustrates these factors.

When we analyze the Table $\mathrm{V}$, it can be said that user comments provide trust at internet shopping. Because, those who purchase over the internet seek a trustworthy system in the face of this uncertain environment. In addition, seen that the orientation effect of user comments. In other words, user comments orient customers to the most appropriate one.

According to a study made by Postcode Anywhere (2011) 251 of 1000 participants said user comments are very important and useful [23]. So it supports this study. As said before user comments are very important to build trust in virtual environments. Because consumers don't have the chance of testing the products physically and they use this online word of mouth system to build trust in reliance upon previous consumer's experiences.

TABLE V: FACTORS

Factor 1: Trust Providing

\begin{tabular}{ll}
\hline $\begin{array}{l}\text { User comments are effective to build trust } \\
\text { through e-shopping. }\end{array}$ & 0,812 \\
\hline $\begin{array}{l}\text { User comments are effective to build trust } \\
\text { through e-retail website. }\end{array}$ & 0,805 \\
\hline $\begin{array}{l}\text { I believe that previous users wrote comments } \\
\text { sincerely. }\end{array}$ & 0,761 \\
\hline $\begin{array}{l}\text { User comments are effective to build trust } \\
\text { through electronic product. }\end{array}$ & 0,758 \\
\hline $\begin{array}{l}\text { User comments are effective to build trust } \\
\text { through the brand. }\end{array}$ & 0,757 \\
\hline \begin{tabular}{l} 
I trust to user comments. \\
\hline $\begin{array}{l}\text { Positive user comments effect electronic product } \\
\text { purchasing decision. }\end{array}$
\end{tabular} & 0,704 \\
\hline $\begin{array}{l}\text { The number of read/like of user comments effect } \\
\text { electronic product purchasing decision. }\end{array}$ & 0,687 \\
\hline $\begin{array}{l}\text { To build trust it's also important for me the } \\
\text { number of user comments. }\end{array}$ & 0,682 \\
\hline $\begin{array}{l}\text { The existence of user comments show me any } \\
\text { shopping have been made before from that } \\
\text { website. }\end{array}$ & 0,635 \\
\hline $\begin{array}{l}\text { If I'll buy a higher price of electronic product, I } \\
\text { read user comments absolutely. }\end{array}$ & 0,603 \\
\hline $\begin{array}{l}\text { I believe user comments are useful. } \\
\text { consumers. }\end{array}$ & 0,522 \\
\hline $\begin{array}{l}\text { I believe that e-retail websites are impartial while } \\
\text { factor } 2 .\end{array}$ & 0,414 \\
\hline
\end{tabular}

\section{Factor 2: Orientation}

\begin{tabular}{ll}
\hline $\begin{array}{l}\text { I read user comments before purchasing } \\
\text { electronic products. }\end{array}$ & 0,766 \\
\hline $\begin{array}{l}\text { I look into user comments before purchasing } \\
\text { electronic products. }\end{array}$ & 0,643 \\
\hline $\begin{array}{l}\text { User comments provide convenience to reach } \\
\text { knowledge of electronic products. }\end{array}$ & 0,641 \\
\hline $\begin{array}{l}\text { User comments provide convenience to compare } \\
\text { electronic products. }\end{array}$ & 0,641 \\
\hline $\begin{array}{l}\text { Awareness of the e-retail websites is also } \\
\text { important for me. }\end{array}$ & 0,637 \\
\hline $\begin{array}{l}\text { While purchasing electronic goods the price level } \\
\text { is important for me. }\end{array}$ & 0,508 \\
\hline $\begin{array}{l}\text { I do an extensive research before buying } \\
\text { electronic products. }\end{array}$ &
\end{tabular}

\section{DISCUSSION}

As we said before information technologies bring lots of risk and uncertainty in virtual environments. To get rid of this consumers seek a trustworthy system and at this point user comments help consumers to decrease the risk perception. Accordingly, the benefits of user comments can be explained as below;

1) User comments help to customers to build trust by increasing e-commerce knowledge and decreasing the risk perception. Because consumers read user comments before the e-shopping and this helps them to gain information about the process. 
2) User comments are a good example of impersonal trust with the help of word of mouth. This function of user comments affects potential customers to buy or not from the website. This is also associated with altruism. Because one of the reasons the previous users to write comments is helping others.

3) User comments are associated with help or revenge enterprise. Because consumers' perception change according to e-shopping process. It means they can help or blow the company with only a few words.

4) User comments reduce the uncertainty due to the nature of the e-commerce. Because, user comments give a signal to inexperienced consumers to buy or not. Unless uncertainty decreases, consumers won't be willing to shop from the internet.

5) User comments occur in a specific order. The order is from basic to top like this; the website, the product, the brand and the e-shopping. This shows us that the most important point is the e-retail website which is the first interaction of e-consumer and the company. Based on this order, user comment trust pyramid can be drawn like Fig. 1.

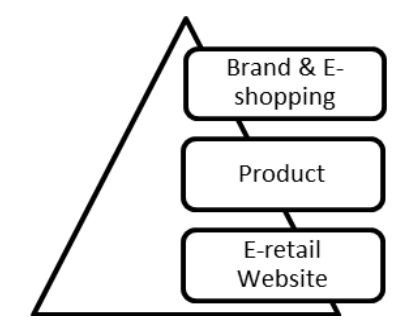

Fig. 1. User comment trust pyramid.

\section{REFERENCES}

[1] R. M. Morgan and S. D. Hunt, "The commitment-trust theory of relationship marketing," Journal of Marketing, vol. 58, pp. 20-38, July 1994.

[2] D. Gefen, E. Karahanna, and D. W. Straub, "Trust and TAM in online shopping: an integrated model," MIS Quarterly, vol. 27, pp. 51-90, March 2003.

[3] B. Oğuztürk, Trust Responsibility, İstanbul: Vedat Pub., 2008, pp. 4.

[4] J. Weiseberg, D. Te'eni, and L. Arman, "Past purchase and intention to purchase in e-commerce: the mediation of social presence and trust," Internet Research, vol. 21, pp. 82-96, 2011.

[5] S. J. Yoon, "The antecedents and consequences of trust in online purchase decisions," Journal of Interactive Marketing, vol. 16, pp. 47-63, March 2002.

[6] M. Fasli, "On agent technology for e-commerce: trust, security and legal issues," The Knowledge Engineering Review, vol. 22, pp. 3-35, March 2007.
[7] S. P. Shapiro, "The social control of impersonal trust," American Journal of Sociology, vol. 93, pp. 623-658, November 1987.

[8] F. Li, D. Pienkowski, A. V. Moorsel, and C. Smith, "A holistic framework for trust in onlie transactions," International Journal of Management Reviews, pp. 1-19, 2011.

[9] D. C. Mutz, "Social trust and e-commerce: experimental evidence for the effects of social trust on individuals' economic behavior," Public Opinion Quarterly, vol. 69, pp. 393-416, Fall 2005.

[10] Y. H. Tan and W. Thoen, "A logical model of trust in e-commerce," Electronic Markets, vol. 10, pp. 258-263, June 2011.

[11] X. Liu and K. K. Wei, "An empirical study of product differences in consumers' e-commerce adoption behavior," Electronic Commerce Research Applications, vol. 2, pp. 229-239, Autumn 2003.

[12] S. M. Furnell and T. Karweni, "Security implications of electronic commerce: a survey of consumer and business," Internet Research, vol. 9, pp. 372-382, 1999.

[13] R. Li, J. J. Kim, and J. S. Park, "The effects of internet shoppers' trust on their purchasing intention in China," Journal of Information Systems and Technology Management, vol. 4, pp. 269-286, October 2007.

[14] G. E. Bolton, E. Katok, and A. Ockenfels, " How effective are electronic reputation mechanisms? An experimental investigation," Management Science, vol. 50, pp. 1587-1602, November 2004.

[15] R. Aksoy, "Trust as the value of marketing and trust attitudes of consumers through electronic markets," Journal of Zonguldak Karaelmas University Social Sciences, vol. 2, pp. 79-90, 2006.

[16] A. Angriawan and R. Thakur, "A parsimonious model of the antecedents and consequence of online trust: an uncertainty perspective," Journal of Internet Commerce, vol. 7, pp. 74-94, 2008.

[17] A. Beldad, M. Jong, and M. Steehouder, "How shall I trust the faceless and the intangible? A literature review on the antecedents of online trust," Computers in Human Behavior, vol. 26, pp. 857-869, April 2010.

[18] A. Yaylı and M. Bayram, "E-consumer reviews: An evaluation on the restaurants of Antalya," 4. National Symposium of Gastronomy \& Artistic Activities Proceedings, pp.1-6, 2010.

[19] C. Dellarocas, "The digitization of word of mouth: promise and challenges of online feedback mechanisms," Management Science, vol. 49, pp. 1407-1424, October 2003.

[20] J. Fan, "Research on the external factors of consumer releasing online comments," International Conference on Electronics \& Mechanical Engineering and Information Technology, pp. 3819-3823, 2011.

[21] R. C. MacCallum, K. F. Widaman, S. Zhang, and S. Hong, "Sample size in factor analysis," Psychological Methods, vol. 4, pp. 84-99, March 1999.

[22] E. E. K. Kim, A. S. Mattila, and S. Baloglu, "Effects of gender and expertise on consumers' motivation to read online hotel reviews," Cornell Hospitality Quarterly, vol. 52, pp. 399-406, 2011.

[23] Postcode Anywhere. Women read online reviews - men don't. [Online]. Available: http://www.postcodeanywhere.co.uk

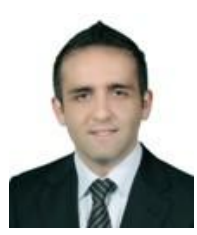

E. Yıldırım was born in 1987. E. Yıldırım finished business administration at Anadolu University, Turkey at 2009. He is at the first term of the third class in 2008 and went to Karel de Grote Hogeschoo Antwerpen, Belgium with Erasmus. In 2010 he started to master at the Institution of Social Sciences at Anadolu University, Turkey and completed in 2012. Now he is a PhD student at Sakarya University, Sakarya. The author's major field of study is e-commerce. 